\title{
The Explicit Teaching of Writing Using Disquisition-Based Learning Strategy for the First Year EFL College Students at Universitas Islam Negeri Maulana Malik Ibrahim Malang
}

\author{
Agus Eko Cahyono; Masrokhin \\ Universitas Islam Negeri Maulana Malik Ibrahim Malang, Indonesia \\ http://dx.doi.org/10.18415/ijmmu.v8i12.3365
}

\begin{abstract}
This current study is directed to implement Disquisition based learning strategy in improving the students' ability in writing descriptive text at the first year EFL college students of Universitas Islam Negeri Maulana Malik Ibrahim Malang. The English major in the first year has eight classes. This site is chosen for several reasons. First, the researcher is a lecturer of the university. Second, the lecturer's strategy in teaching text writing is not varied. Third, the researcher is motivated to solve the students' problems in writing texts. This study is categorized as a collaborative action research since in conducting the research, the researcher works collaboratively with a classroom English lecturer in the research activities at the stage of planning, the implementation of the action, the observation and the analysis and reflection. Based on the study's findings and discussion, it can be concluded that using a Disquisitionbased learning strategy can help students enhance their capacity to write descriptive paragraphs. Furthermore, it provided students with opportunities for increased independence. They can work together without the lecturer dictating every step, and they can make some of their own learning decisions to complete the task, due to peer revising and editing activities. Furthermore, the strategy necessitates that the students collaborate. It emphasizes the importance of group collaboration to solve problems and obtain a diverse range of feedback or replies to difficulties. In group learning, it allows students to share their thoughts with one another and to learn to listen to and respect the viewpoints of their peers. Furthermore, the execution of this strategy has a favorable impact on students' interest in learning English. The researcher noticed that a couple of the students who used to run away from class when he first started teaching were already participating in all of the learning activities. The future researcher is advised to implement and build a Disquisition-based learning strategy in other school levels. However, in the implementation the strategy, the lecturer should give more guidance and data sources such as interesting pictures, a large number of vocabulary, and simple models of writing.
\end{abstract}

Keywords: Explicit Teaching of Writing; Disquisition-Based Learning Strategy; The First Year EFL College Students

\section{Introduction}

A descriptive text is a type of text that is taught to first-year EFL college students who are majoring in English. In descriptive texts, the authors are frequently required to define individuals, items, 
or locations. They eloquently convey their ideas and thoughts based on what they see, hear, taste, smell, or touch (Azhari, 2004). In comparison to narrative, accounting, or procedure, a descriptive text is considered the simplest and easiest style of writing, especially for beginning authors (Ellis et al., 1989). It also allows students to share interesting perceptions of a person, a place, or an object in their environment (Troyka, 1987).

Writing is the most difficult and sophisticated language talent to learn when compared to other abilities such as listening, speaking, and reading. Writing mechanics, word choice, syntax, and the ability to integrate words in written speech to form a coherent thought are all contributing factors. According to Riyanto (2001), three variables contribute to learners' difficulties in writing: a lack of vocabulary, a lack of mastery of English grammar, and a lack of exercise. Writing practice has been inadequately provided due to a lack of exercises and motivation for the students. As a result, many students are having difficulty in writing.

Furthermore, according to Byrne (1988), writing is difficult for students since they are required to write on their own, struggling to perfect their compositions without communication or criticism from other students or teachers. He goes on to state that learners must write their texts in writing and organize their own thoughts in such a way that readers can grasp their works by using their own choice of phrase structure.

The English Department of Universitas Islam Negeri Maulana Malik Ibrahim Malang discovers data about the teaching of English in general and the teaching of writing in particular based on informal interviews with colleague English teachers. The integration of the four linguistic talents is used in English education. Writing ability development assignments are scheduled for 90 minutes per session, twice a week. Due to time constraints, the additional activities offered to the students should be completed as a home assignment. Students are frequently assigned to write a recommended subject in the traditional style of teaching writing at the university level, give in their work, and then receive it back with a mark on their errors.

As a result, students have trouble putting their thoughts on writing. Students are unable to string their words together to form a phrase and then organize the phrases into a useful text. This condition has an impact on the students' ability to write text. Most students, on the other hand, had little confidence in their ability to write. They had no incentive to write due to their lack of comprehension of syntax and vocabulary, therefore they were unable to articulate their views in written language. In addition, some students utilized inadequate writing skills. They did not know where to start or how to organize the structure.

The foregoing issues could have been caused by a variety of factors. First, the lecturer sets the students to create a piece using the teaching writing approach without providing any guidance. The lecturer is only requesting that the students write a text. Second, during the writing process, the lecturer does not provide students the opportunity to debate and share their ideas. Finally, the lecturer does not provide a text organization model. Fourth, the lecturer never delivers a written lecture to address the learners' concerns and assist them in identifying grammatical problems. Furthermore, learning materials are not always directly applicable to real-life situations. As a result, they are exhausted and resentful of their writing responsibilities.

Given the foregoing circumstances, it is critical to find a strategy that can give learners with a healthy learning environment in order to actively participate in the teaching and learning process of writing. Some ways have been developed in order to develop meaningful written teaching and learning. Disquisition-based learning is a method of teaching that aims to improve students' writing abilities.

According to Bevilacqua (1990), the Disquisition-based learning strategy encourages learners to generate as many thoughts as possible in order to develop concepts for the target subject through 
observing actual stuff around the campus. The lecturer assists the students in creating a text. Students are also assigned to share and debate the challenges they experience in writing in terms of language use with their peers. After publishing the finished writing text, the lecturer arranges a meeting to discuss and resolve the challenges that students have when writing descriptive text.

Meanwhile, according to Lee (2004), Disquisition-Based Learning refers to a variety of classroom strategies that use modeling, instruction, and research to inspire learners to learn. Learners are responsible for the development and maturity of their own teaching and intellectual development when they engage in disquisition-based learning. The research process is guided by one's own curiosity, wonder, interest, or passion in order to interpret an observation or resolve an issue.

The researcher is planning a survey using Disquisition-based learning to address the issues of writing skill that EFL learners at Universitas Islam Negeri Maulana Malik Ibrahim Malang have encountered. It is expected that completing the survey to improve the learners' writing skills will provide a way out. In keeping with the study's background, the current study aims to use a Disquisition-based learning strategy to help students improve their capacity to write descriptive language. As a result, the research question is "How might a Disquisition-Based Learning Strategy increase the ability of first-year students to write descriptive text?"

\section{Research Methods}

This study is classified as a collaborative action research because the researcher collaborates with a classroom English lecturer in the research activities at the design, execution, observation, analysis, and reflection stages. The researcher and the English lecturer collaborate on lesson planning as well as the preparation of instructional materials and media. During the implementation stage, the researcher takes on the role of the teacher in the classroom. His collaborator takes a seat in the back of the room and acts as the observer for the classroom observation. Using observation checklists and field notes, the collaborator monitors the students' activities while applying the plan. After implementing the strategy, the students are given a writing test in which they are asked to make a descriptive text to measure their ability in writing. Then, after the data are collected either from observation checklists, field notes or the result of the test, the researcher and the collaborator analyze the data to know whether the criteria of success proposed have been achieved or not.

The first-year EFL college students from Universitas Islam Negeri Maulana Malik Ibrahim Malang, located at Jl. Gajayana 50 Malang, participated in this study. In the first year, the English major has eight classes. This location was chosen for a variety of reasons. First and foremost, the researcher is a university lecturer. Second, the lecturer's teaching strategy for text composition is consistent. Third, the researcher is motivated to help students with their writing challenges.

The following steps are used in this classroom action research: (1) preliminary research, (2) planning, (3) implementation, (4) observation, (5) data analysis, and reflection. The research processes are as follows: Kemmis and McTaggart's procedures have been adapted (1998). Planning, implementing, observing, and reflecting are the four steps proposed by Kemmis and McTaggart in their original approach. The terms preparatory study, data analysis, and reflection are added by the researcher to the methods. He believes that conducting a preliminary investigation is critical in order to understand the true issues that students experience in the writing teaching and learning process. It is intended that by understanding the true issues that the students face, the researcher will be able to devise an effective plan to address them. The researcher then adds the terms of data analysis because analyzing data is very important to find out the results of the research. Meanwhile, adding of reflection terms is due to the characteristic of classroom action research is reflective thinking. Syamsudin \& Damaianti (2007) state 
that in classroom action research reflective thinking is very important for researcher to do retrospection on the action having been done. The reflection is as a basis of doing the next action.

The preliminary research is conducted to understand more about the students' current situation as well as the lecturers' challenges in the teaching and learning process. The researcher observes the class and offers the students a pre-test on descriptive text to determine the students' engagement during the teaching of writing, particularly in the teaching of text writing, and to obtain a true description of the students' challenges in producing texts. The students are required to complete a writing test that the researcher has created. It is carried out to assess the students' current writing abilities before the strategy is adopted. During the second and third quarters, it is on hold.

The students do not know where to begin writing a simple descriptive text, they struggle to come up with writing ideas, and they are not engaged in the writing class, according to the findings of the observation. Meanwhile, the test results suggest that the students' writing abilities are limited. The papers lack clear and detailed information, the majority of phrases are unrelated to the core topic and are not rationally structured, and the texts contain numerous grammatical errors.

The researcher and the collaborating English lecturer discuss and construct a model of Disquisition based learning approach in teaching descriptive literature to ensure that the teaching and learning process runs smoothly. The students are divided into groups when implementing the strategy. The students are divided into groups based on their writing pre-test scores in order to generate a more diverse group. Each group comprised of five or four students. Higher students might potentially share ideas and collaborate with lower students to complete the task assigned throughout the teaching and learning process with the help of such an organization. Table 1 shows the general requirements for using the Disquisition-Based Learning Strategy for teaching descriptive texts (in appendix).

There are a few approaches for judging students' writing that might be used. Holistic scoring method, analytic scoring rubric, and key trait are a few of them. In terms of writing aspects to evaluate, the three ways differ from one another. The study's scoring approach is analytic scoring rubric, which evaluates the components of writing. The assessment of this study focuses on the content, organization, and language use. This grading approach was chosen because it offers a number of benefits. According to O'Malley (1996), the scoring approach can give students feedback on specific parts of their writing, as well as lecturer diagnostic information for organizing instruction.

The researcher employs the inter-rater method to grade the students' writing. This necessitates the use of two raters to grade the students' work. The researcher and the collaborator are the two raters. Students utilize a scoring guide for writing (see Table 2 in appendix) derived from Heaton to score their papers (1990). Content, organization, language use, and mechanics are the four components of writing that were assessed in the original grading guide. The component of mechanics is ignored in this study since the mechanics portion is still tough for first-year EFL college students. As a result, just three aspects of writing are evaluated when students write, namely content, organization, and language use. Each component of the text written by the students is scaled of $1-4$. The maximum score is 12 ( $4 \times 3)$, and the minimum score is $3(1 \times 3)$.

In terms of substance, the student's writing is graded (4) if it presents information with details throughout the text; (3) if it offers information with details in sections of the text; (2) if it presents information with some details; and (1) if it presents no clear information. When it comes to organization, it's counted as (4) if the majority of the sentences are related to the main idea and logically ordered; (3) if some sentences are related to the main idea but not logically ordered; (2) if a few sentences are related to the main idea but not logically ordered; and (1) if the sentences are unrelated to one another. It is computed (4) if there are few grammatical inaccuracies; (3) if there are a few grammatical inaccuracies; (2) if there are numerous grammatical inaccuracies; (1) if there are frequent grammatical inaccuracies when it comes to language use. 


\section{Research Findings and Discussion}

The findings are a combination of the two cycles' findings. The first cycle took place on August $15^{\text {th }}, 17^{\text {th }}$, and $22^{\text {nd }}, 2019$; the second cycle took place on September $19^{\text {th }}, 21^{\text {st }}$, and $26^{\text {th }}, 2019$. The planning of the action, the implementation of the action, the analysis, and the reflection of the action are all covered in the description of each cycle. Meanwhile, the debate focuses on how to teach and learn writing using a Disquisition-Based Learning strategy, as well as how to develop students' writing skills.

\section{Findings of Cycle I}

Some preparations and discussions are carried out before conducting the teaching and learning process in the classroom. Preparing the lesson plan, which includes the teaching schedule, instructional objectives, instructional materials and media, instrument of observations, and assessment, is part of the preparations. Cycle one was taught in three meetings, according to the teaching timetable. The first meeting was held on January 15, 2019, the second meeting was held on January 17, 2019, and the third meeting was held on January 22, 2019. The first cycle's teaching and learning process was divided into three sessions. The first meeting concentrated with pre-writing activities, second meeting dealt with drafting and revising, while the third meeting focused on editing and publication. Each meeting had a time limit of $2 \times 40$ minutes.

The students were supposed to be able to gather ideas for the real object they chose, choose relevant thoughts for the topic, title their paragraphs, and create paragraph outlines during the first meeting. (1) discussing some pictures shown by the lecturer, (2) grouping the students, (3) going outside the class and observing objects chosen by involving the students' senses, (4) sharing ideas the students gained from the observation, and (6) making an outline were the activities of the pre-writing stage.

The students were supposed to know the characteristics of descriptive paragraphs, produce a first draft, and modify the content and organization of the document at the second meeting. The following were the activities in the second writing: The lecturer began by demonstrating a model descriptive paragraph and discussing it with the students. The students then completed the first draft of their writing. Third, the students exchanged their writing with their peers and provided feedback and suggestions on their peers' work. Finally, the students used the revision guide questions to improve the substance and organization of their classmates' writing.

Students were expected to be able to revise their drafts for language use (grammar), proofread the drafts, create the final writings, and publish their papers by the third meeting. The third meeting's activities included using the editing guiding questions to edit the draft's language use (grammar), proofreading the text, producing the final draft, and publishing the students' writings by reading them in front of the class.

The assessment of the teaching and learning process included both ongoing and final product evaluations. Ongoing assessment was carried out as part of the teaching and learning process, and it was done by observing the students' participation in the process. The focus of the product evaluation was on the students' writing tests, which were administered after the teaching and learning process. The test format was paragraph writing, and each student was given the task of producing a descriptive paragraph of at least seven related sentences depicting an image of a mango tree.

The information gathered from the observation sheets and filed notes were used to conduct an analysis of the teaching and learning process. During the teaching and learning process, the lecturer's and students' activities and responses were provided in the analysis. According to the data gathered, not all students participate actively in the teaching and learning process. Some students, for example, did not pay attention to the lecturer's explanations. They only shifted their attention to the lecturer when he requested them to. Other students with the initials AZ, MH, ML, MM, and RG engaged in non-assigned activities 
such as writing and drawing in their own workbooks. Furthermore, throughout the group discussion, some students did not talk or exchange thoughts with one another. They did not take part in the discussion except the lecturer asked them to. Besides, many students of the groups work individually. They did not make some interaction with their group members.

According to the collaborator, during prewriting, $40 \%$ of students (equal to poor) discussed the pictures by answering the lecturer's questions, $75 \%$ (equal to good) students gathered some information related to the object by making notes, and 50\% (equal to fair) students shared their ideas with others in their group and created an outline in order to generate their idea. In whilst writing, only 45 percent (equal to fair) students discussed the models of descriptive paragraph with the lecturer, 75 percent (equal to good) students wrote the first draft, 70 percent (equal to good) students reread and review the drafts, 45 percent (equal to fair) student gave comments and suggestions, 65 percent (equal to good) students checked their draft, and 65 percent (equal to good) students revise their drafts on content and organization. In post writing, $65 \%$ (equal to good) students checked the drafts, $60 \%$ (equal to fair) proofread their friends' drafts, $65 \%$ (equal to good) students edited their drafts in terms of language use(grammar), and only $40 \%$ (equal to poor) students reflected about the learning process of making descriptive paragraph. In general, the participation of the students in the first cycle was 58\% (equal to fair). The qualification of the students who participate during the writing activities in the Cycle one was shown in Table 3 (see in appendix).

Some issues were discovered during the implementation of the activities in meetings one, two, and three, according to the field notes. For starters, some students misunderstood the lecturer's reasoning. The lecturer's explanations were primarily in English, which could have contributed to the situation. Second, the students' difficulties were primarily related to conveying their views in English, resulting in grammatical faults in their compositions. Because not all students had sufficient English vocabulary to write, they looked up words in dictionaries most of the time, and some of them even wrote an Indonesian language version of their descriptive paragraph before translating it into English. Incorrectly, the quantity of dictionaries offered was insufficient to accommodate the number of students and groups.

The writing of the first cycle's students was gathered and assessed. Both the lecturer and the collaborator discussed and rated the students' writing one by one using the scoring guide when analyzing their work. The focus of the study was on three aspects of writing: content, organization, and language usage. According to the findings, the students continued to make mistakes in terms of content, structure, and language usage. The majority of the students' writings contain some detailed material that is difficult to comprehend. The majority of students structured their writing concepts almost clearly, but there was no logical sequencing. Furthermore, they still contained minor grammatical faults. On table 4, you may see examples of errors in students' writing from cycle one.

Table 4 provides examples of grammatical errors produced by the learner on a regular basis. The blunders revealed that the students still had a poor understanding of English grammar. The children, for example, struggled with subject-verb agreement. Another issue was that there were no articles. Because the articles are not often utilized in Bahasa Indonesia, this happened. Furthermore, students struggled with the proper placement of adjectives before the nouns they modified in English noun phrases. They also had a trouble with the plural form in English.

The implementation of the Disquisition-Based Learning method did not yet yield adequate results on the enhancement of students' writing ability, according to the examination of the teaching and learning process and the students' writing in the first cycle. The observation checklist and field notes revealed that the students were not fully engaged in the teaching and learning process. Only 58 percent of students were engaged in the teaching and learning process (equal to fair). Some factors contributed to the students' poor performance. To begin with, it was caused by the lecturer's explanations and instructions, which were largely presented in English and so were not understood by the students. As a result, they were unable to 
do their responsibilities effectively. Second, it was caused by the students' insufficient skill on grammar that sometimes they generated improper grammatical sentences. Third, it was created by the lecturer's lack of direction to students at all stages of their education Forth, it was caused by the way of grouping students. Next, it was caused by insufficient number of dictionary provided in the teaching and learning process. There were two standard dictionaries, and several pocket dictionaries in class. Some students attended the English class without any dictionaries at all. Considering the problems mentioned above, the lecturer and the collaborator made a decision to continue the action to the second cycle. The lesson plan and the preparation of the study in the second cycle were revised and improved.

\section{Findings of Cycle 2}

The cycle's outcome I have not yet met the success criteria. As a result, some revisions should be made in the areas of requiring more explanation and instruction in Indonesian, requiring more explanation of grammar, especially those related to the topic discussed, requiring to intensify guiding students through every stage of the writing process, requiring to equip students with a dictionary, and time management.

In terms of instruction and explanation, the lecturer and collaborator agreed to use Indonesian to clarify things. The lecturer was also instructed to speak slowly so that the entire class could grasp what he was saying. Furthermore, the lecturer should respond to students who disrupt the session by creating noise or chatting about unrelated topics. Concerned with reducing the quantity of grammatical errors committed by students when writing descriptive paragraphs, he reminded the students on the proper use of word order, article, subject verb agreement or grammatical use (to be, do, and have) in English, as well as plural forms.

The students were provided extensive instruction at every stage of the process writing. When the students were focused on their work, the lecturer guided them without waiting for them to ask questions. This was done because, despite the fact that the students were having difficulty completing their job, some of them were hesitant to seek assistance from the lecturer.

In terms of student grouping, the lecturer divided the students who were disruptive (in Cycle 1) into two groups. Finally, the amount of time that will be spent on each activity in each meeting will be determined. In order to reduce the number of students who use dictionaries, the lecturer asked students to borrow dictionaries from students in other classes. The lecturer provided them extra time in the afternoon to show them how to use the dictionary to find words because they were having trouble researching English words in the dictionary. Before beginning the teaching and learning activities, the lesson plan was created in addition to the above preparation. Generally, the procedures of instruction and the procedures of assessment were the same as that of in the first cycle since the action was mainly to continue the teaching and learning process in order to achieve the criteria of success.

The information gathered through observation checklists and field notes is used to analyze the teaching and learning process. The data pertains to the students' involvement in the teaching and learning process. According to the data, students were more active during the process in three meetings of Cycle 2 than they were in Cycle 1. They were, for example, more engaged throughout the group discussion. The new student grouping structure reduced the number of students who made noises or engaged in unrelated activities during group discussions. Furthermore, almost all students pay close attention while the lecturer is explaining something, and they participate actively in the teaching and learning process. Table 5 shows the percentage of students who stay on task during the teaching and learning process.

Table 5 shows the data concerning the students' activities during the implementation of the action in Cycle two. According to the table, the average of the students' participation in writing activities increased from Cycle one to Cycle two. In prewriting, it was discovered that $75 \%$ of students (equal to good) discussed the pictures by answering the lecturer's questions, $85 \%$ (equal to very good) students gathered some information related to the object observed by taking notes, and $80 \%$ (equal to good) 
students shared their ideas with others in their group and created an outline in order to generate their idea. While writing, $70 \%$ (equal to good) students discussed descriptive paragraph models with the lecturer, $100 \%$ (equal to very good) students wrote the first draft, 75 percent (equal to good) students reread and reviewed the drafts, 65 percent (equal to good) students provided comments and suggestions, 80 percent (equal to good) students checked their drafts, and $70 \%$ (equal to good) students revised their drafts on content and organization. In post writing, $75 \%$ (equal to good) students checked the drafts, $75 \%$ (equal to good) proofread their friends' drafts, $80 \%$ (equal to good) students edited their drafts in terms of language use (grammar), and only 65\% (equal to good) students reflected about the learning process of making descriptive paragraph. Generally, the participation of the students in the second cycle was $78 \%$ (equal to good).

Some facts were discovered during the implementation of the activity in the second cycle, according to the field notes. First, because the students were given more flexibility and direction in the paragraph-writing process, they were able to generate acceptable paragraphs with fewer errors than in the prior cycle. Second, the majority of students were able to comprehend the lecturer's explanation or instruction. It's possible because the lecturer taught or directed in English first, then translated it into Indonesian. He could also raise his voice to make his explanation or instruction audible to the entire class. Third, everyone in the group works together. Because each member was given the opportunity to speak, even the students with low achievement were able to do so. During the teaching and learning process, no more students made descriptive behavior or talked irrelevant matters since the lecturer monitored them. In doing peer editing, each student could give his/her correction to their friends as well as their own draft. Last, the time management had also been implemented appropriately. He could apply each activity in line with the time allotment that had been set for each activity.

Cycle 2 students' writing was collected and examined in the same way that cycle 1 students' writing was collected and evaluated. One by one, the lecturer and collaborator analyzed and graded the students' essays. The focus of the study was on three aspects of writing: content, organization, and language usage. According to the findings, the students were able to write a great amount of words in their descriptive paragraph. They were also able to write an understandable descriptive paragraph with good substance and organization. However, the students' descriptive paragraph contained some grammatical faults, though not as many as the errors they made in cycle one. Table 6 shows examples of faults made by students in their writing.

The Disquisition-Based Learning strategy could improve students' writing abilities, based on the results of the examination of both teaching and learning processes and the students' writing scores in Cycle 2. The success criteria stated in this study can be used to investigate this. First, students were more engaged in the teaching and learning process, as evidenced by observation checklists and field notes indicating that all activities were carried out properly.

\section{Discussion}

According to the findings of the study, the best model for teaching writing paragraphs using the Disquisition-Based Learning approach needs the lecturer to use a specific strategy at each stage of the process writing, which includes prewriting, writing, and editing. Prewriting entails everything students do before starting the real writing job, such as activating background knowledge, developing ideas, and establishing preparations for how they will approach the writing task (Christenson, 2002:41). The lecturer devised two crucial strategies for this purpose: conversation and outline.

The lecturer held a discussion with the students before moving on to the main materials. It served as a springboard for engaging the students' prior understanding of the topic at hand. Students were asked to answer a series of questions orally in this strategy. This was done for two reasons: to introduce the 
students to the topic they would be studying and to make it easier for them to recall relevant facts that would help them internalize new information.

The lecturer then divided the students into small groups. The students were divided into groups based on their pre-test scores. The students were divided into eight small groups, each with an average of five different students. The main justification for grouping five students together was that a smaller group would be more productive than a larger one because it took less time to organize. Furthermore, the time allotted for the writing session was fairly restricted, thus the small group discussion was more acceptable. This was in line with Johnson et al. (1991), who stated that the smaller the group, the shorter the time available. After then, the seating for the various groups was determined. The students were seated face-toface so that they could see each other and discuss ideas.

It is more beneficial to work in groups than it is to work alone. When a student is having trouble writing a paragraph, he or she can ask his or her peers. Smart students can assist low-achieving students. It means that the slow students can benefit from the knowledge of the smart students. According to Salvin (1995:17), group learning becomes an activity that allows students to advance in their peer groups. He goes on to say that the value of a group is in giving students with an incentive to support one another and to urge one another to put forth the least amount of effort possible.

The lecturer used the outlining method to encourage the students to conduct research for writing. A collection of general and specific topics that will be presented in the essay is called an outline (Turkenik, 1999:58). He goes on to argue that an outline can help a writer recall what they want to convey and arrange their thoughts before they start writing. The outline is more useful since it assists the writer in organizing his thoughts so that he does not have to think about what to write. According to Eanes (1997:491), an outline is a useful tool in the planning process, particularly for students starting to write. In other words, there is a representation of a half-written text that has already been expanded by a writer into a paragraph or essay. The writer just expands on what he or she wrote in the outline. In this stage, the students were given a chance to pour ideas with guidance from the lecturer. Hence, the lecturer's role was a facilitator in order to help the students to explore and pour their ideas into the rough draft.

The students begin drafting activities in the While Stage. The process of putting ideas on paper is known as drafting (Christenson, 2002:41). Brown (2001) goes on to say that drafting is considered as a critical and difficult collection of strategies that requires time, patience, and expert education to master. Because drafting is seen as a complex and challenging action in the writing process, the students were given a model of a rough to assist them in overcoming their difficulties. During the editing process, the lecturer employed modeling and discussion strategies.

The students were able to understand the type of writing they were meant to write by seeing a model of text. They should produce a descriptive paragraph for this study. That was in accordance with Temple et al. (1988: 48), who stated that "having a lot of models around them is the best approach to encourage youngsters to explore writing - both the act of writing and the writing that is produced." Brown (2001:347) argues that "students can obtain valuable knowledge both about how they should write and about subject matter that may become the theme of their writing" by reading and studying a variety of relevant styles of text. As a result, giving the model text becomes an effective method that may be used throughout the drafting stage to allow students to express their ideas in accordance with the writing form that they are expected to use.

In addition, the material should be presented followed by a debate. The students were able to grasp the writing structure and the structuring of concepts into writing through conversation. The lecturer, on the other hand, should provide her with advice by asking questions to ensure that the students comprehended the model text. The students were also encouraged to revise their manuscript at this point. The process of revising entails rethinking and modifying what has already been written (Calderonello \& Edwards, 1986). The second draft is formed by rethinking and rewriting the first draft. It was done in 
order to create a draft that was clearer and more coherent. According to Smalley et al. (2001), during the revising stage, students are reconsidering or reseeding their text. Revising entails assessing what has already been written. Students make modifications to their rough drafts by adding words, swapping sentences, deleting words or phrases, or moving them.

The lecturer employed modeling and peer revising activities to revise the students' drafts. The students were given a simple rough draft and revising leading questions before beginning the genuine peer revising process. The students were then asked to examine whether the example draft featured a theme, identify supporting information by examining whether all of the sentences in a basic draft referred to the topic sentence or not, and finally, recognize the sentence's sequence.

The students were then introduced to the real peer revising exercise by sharing their own paragraphs with their classmates. The peer revising strategy was chosen to teach students how to independently analyze their peers' work and to boost their self-esteem. According to Harmer (2000), peer work provides students with opportunities for increasing independence. Students worked together without the lecturer supervising every move, they made some of their own learning decisions to complete the task, and they could work without the pressure of the entire class listening to what they accomplished through the peer revising exercise.

The lecturer used a modeling and peer editing method in the post-writing stage. The students were taught a model for modifying a draft utilizing editing leading questions. The students were then taken to the real editing exercise once they had been adequately taught in altering paragraphs through the sample provided. They were instructed to participate in a peer editing activity by sharing their own paragraphs. This was done in order to teach students how to correct their friends' drafts in terms of language usage (grammar). "Peer editing is a true sharing process," according to Brown (2001). Students improved their writing and reading skills as a result of this method. Furthermore, it allowed the students to form close relationships.

The students were also publishing at this time. Students were given the opportunity to publish their final work. This supports Vacca \& Vacca's (1998) assertion that publishing is a pleasurable activity. For students, publishing is highly significant since it allows them to share their writing with a genuine audience of their classmates and other students. Other factors that were considered to have contributed significantly to the students' improvement during the teaching and learning writing paragraph included: (1) clear instruction and explanation, (2) grammatical explanation, (3) intensive guidance, (4) the grouping method, and (5) the need for a dictionary.

The lecturer used both English and Indonesian in his instruction and explanations. This was done to eliminate misunderstandings and to make it easier for students to understand and complete the work. Clear instruction, according to Gebhard (1996), can aid students in staying on task. Grammatical explanation was another crucial component. The lecturer provided additional examples to explain grammatical aspects, particularly those that were utilized more frequently in their paragraph, such as subject verb agreement, article, and word order. This was done because the students struggled to convert Indonesian statements into English equivalents word by word. Furthermore, the lecturer spent time identifying and explaining the mistakes in the students' writing.

In terms of intensive instruction, the reality revealed that, despite having difficulty completing their assignment; some students were hesitant to seek assistance from the lecturer. When the students were on task, the lecturer proactively asked issues rather than waiting for them to come up with their own. Having students work in groups is critical because it not only makes the process more engaging and pleasant, but it also ensures that the students understand that writing is a collaborative effort. Students engage in writing groups and collaborate on compositions (Hamp - Lyons \& Heastey, 1987). 
The students' failure to order their thoughts was primarily due to their lack of vocabulary. As a result, a dictionary was required to assist students in expanding their vocabulary in order to generate a phrase with more relevant words. According to Cohen (1990), a dictionary is useful for double-checking words that are not easily understood from context. Similarly, Nation (2000) claims that a dictionary can aid with comprehension. In terms of student participation in the teaching and learning process, it was discovered that in the first cycle, some students did not take all activities seriously, with only 58 percent of students actively participating in writing activities. Meanwhile, in cycle 2, 78 percent of students completed the teaching and learning activities successfully.

Disquisition-Based Learning can help students enhance their descriptive paragraph writing skills. The outcomes of the students' writing based on the writing task given at the end of the cycle can be used to assess the improvement. Prior to using this teaching strategy, students had a lot of trouble writing in English. Their writing is riddled with flaws in content, organization, and language usage. Students who have been trained in the teaching of descriptive writing using the Disquisition Based Learning technique can write relatively comprehensible descriptive paragraphs, as the substance and organization of the paragraphs have improved, while the frequency of grammatical errors has decreased.

In terms of writing substance, the majority of students' compositions in the pre-test are relevant to the topic yet difficult to comprehend. Because the students had difficulty locating the paragraph's content, there was only a small amount of substance that could be expressed in their writing. However, some students are able to dig up the content of the paragraph in the first post-test, and some of their compositions present material with some details. Meanwhile, most students are able to dig up content in the post-test 2, and most of their papers present information with details in portions of the paragraph.

When it comes to structure, the majority of the paragraphs in the pre-test are not logically ordered, and the sentences in each paragraph are unrelated to the core theme. On the other hand, some students still struggle to organize their paragraphs in the first post-test. Some of their paragraphs are properly organized, and some of their sentences are connected to the main theme. Meanwhile, in post-test 2 , the majority of students can write well-organized paragraphs. The majority of their paragraphs are rationally organized, and some of their sentences are connected to the main concept. Language use is the grading guide's final writing component. During the pre-test, the majority of the students made many grammatical errors. The majority of their paragraphs were riddled with grammatical problems. In the first posttest, some of the students' paragraphs contained grammatical errors. Meanwhile, in the post test 2, only a few of the students' paragraph that still had grammatical inaccuracies.

\section{Conclusions}

It may be inferred, based on the study's findings and discussion, that the Disquisition-Based Learning strategy can increase students' capacity to write descriptive paragraphs. Furthermore, it provided students with opportunities for increased freedom. They can work together without the lecturer dictating every action, and they can make some of their own learning decisions to complete the task, thanks to peer revising and editing activities. Furthermore, the strategy necessitates that the students collaborate. It emphasizes the importance of group collaboration to solve problems and obtain a diverse range of feedback or replies to difficulties. In group learning, it allows students to share their thoughts with one another and to learn to listen to and respect the viewpoints of their peers. Furthermore, the application of this strategy has a favorable impact on students' interest in learning English. The researcher noticed that a few of the students, who at the beginning of his teaching liked to escape from the class, were already active in all activities set during the learning process.

The appropriate model of Disquisition-Based Learning strategy are: (1) engaging students to express their ideas in discussion activities, (2) guiding the students to investigate or observe the objects, 
(3) asking them to make notes of what they have investigated, (4) engaging them to make outline, (5) providing and discussing a model of text, (6) drafting rough draft based the outline, (7) revising the drafts focusing on the content and organization, (8) conducting peer editing in order to edit the grammatical aspects, (9) sharing the writing by reading it aloud in front of the class, and (10) reflecting the process of writing.

The following concerns should be taken into account by lecturers when implementing the plan. First, the lecturer should prepare instructional media, develop instructional processes, and design assessment procedures before beginning to teach. Second, lecturers should employ the outlining strategy for exploring and creating ideas, as well as modeling to show students how to compose, revise, and edit drafts during the writing process. The future researcher is advised to implement and build a DisquisitionBased Learning strategy in elementary school. However, the lecturer should provide additional direction and data sources, such as interesting graphics, more vocabulary, and simple writing models, when using the strategy.

\section{Appendixes}

The appendixes of this study can be accessed through https://bit.ly/3HhckFl

\section{References}

Bevilacqua, A. 1990. Models of Inquiry, (Online), (http://virtualinquiry.com/inquiry/stripling.htm, accessed on July 29, 2007)

Brown, A.C., Nilson, J., Shaw, F.W., \& Richard, A. 1984. Grammar and Composition. Boston: Hughton Mifflin.

Brown, H.D. 2001. Teaching by Principles: An Interactive Approach to Language Pedagogy. New York: Adesson Wesley Longman.

Brown, J.D. 1996. Testing in Language Programs. Upper Saddle River: Printice Hall Region.

Byrne, D. 1998. Teaching Writing Skill. London: Longman Group UK Limited Company.

Calderonello, A.H. \& Edwards, B.L. 1986. Rough drafts: The process of Writing. Boston: Houghton Mifflin.

Christenson, T.A. 2002. Supporting Struggling Writers in the Elementary Classroom. New York: International Reading Association.

Cohen, M. \& Riel, M. 1989. The Effect of Distances on Students' Writing. American Educational Research Journal. 26,2,pp.143-159.

Cohen, D.A. 1990. Language Learning: Insight for Learners, Teachers and Researcher. Cambridge: Nearbury House.

Eanes, R. 1997. Context Area Literacy. Teaching for Today and Tomorrow. USA: Delmar Publisher.

Gebhard, J.G. 1996. Teaching English as a Foreign or Second Language. A Teacher Self-development and Methodology Guide. Ann Arbor: The University of Michigan Press.

Hamp - Lyons, L. \& Heastey, B. 1987. Study Writing: A Course in Written English for Academic and Professional Purposes. Cambridge: Cambridge University Press. 
Harmer, J. 2000. How to Teach English: An Introduction to the Practice of English Language Teaching. Edinburgh Gate: Addison Wesley.

Heaton, J.B. 1990. Classroom Testing. USA: Longman.

Johnson, David, W. Johnson, Roger. T. and Holubec, Edythe. J. 1990. Cycles of Learning Cooperation in the Classroom. (Third Edition). Edina Minnasote: Interaction Book Company.

Kemmis \& Mc. Taggart. 1998. The Action Research Planner. Gee long: Deakin University Press.

Lee, V.S 2004. Teaching and Learning through Inquiry, (Online), (http://micro.magnet.fsu.edu/optics/activities/teachers/kwl.html, accessed on February 23, 2007).

Nation, I,S,P. 2001. Learning Vocabulary in Another Language: Endinburg: Cambridge University Press.

O’Malley, J.M \& Pierce, L.V. 1996. Authentic Assessment for English Language Learner. Practical Approaches for Teachers. New York: Addison Wesly Publishing Company, Inc.

Riyanto. 2001. Peningkatan Kemampuan Menulis Paragraf Singkat Bahasa Inggris yang Koheren dengan Menggunakan Pertanyaan Terstuktur Siswa SMP Kelas III Palembang. Buletin Pelangi Pendidikan. 2 (4): 14.

Salvin, R.E. 1995. Cooperative Learning. Boston: Allyne \& Bacon.

Samsudin, M.S., \& Damaianti, V.S. 2007. Metode Penelitian Pendidikan Bahasa (Edisi Kedua). Bandung: PT. Remaja Rosdakarya.

Smalley, R.L.et al. 2001. Refining Composition Skills. Rhetoric and Grammar ( $5^{\text {th }}$ ed.). Boston: Heinle \& Heinle, A Devision of Thompson Learning.

Temple, C., Nathan, R., Burris, N. \& Temple, F. 1998. The Beginnings of Writing. Massachusetts: Allyn and Bacon, Inc.

Troyka, L. Q. 1987. Simon \& Schuster Handbook for Writers. New York: Prentice-Hall.

Turkenik, 1998. Choices Writing Projects for Students of ESL. New York: Cambridge University Press.

Vocca, R.T \& Vocca, J.L. 1998. Content Area Reading: Literacy and Learning Across the Curriculum. Addeson - Wesley Educational Publisher, Inc.

\section{Copyrights}

Copyright for this article is retained by the author(s), with first publication rights granted to the journal.

This is an open-access article distributed under the terms and conditions of the Creative Commons Attribution license (http://creativecommons.org/licenses/by/4.0/). 